\title{
If Machiavelli had been an emergency physician a CJEM interview
}

Jeffrey Freeman, MD

N iccolò Machiavelli, the Italian philosopher, was renowned for his cunning and often ruthless morality. In reality, Machiavelli's writings suggested practical, decisive and effective measures to achieve the greatest good. Imagine what an interview with him would have been like had he been an emergency physician ...

CJEM reporter: Hello. I'm Melina Borborygmi from the Canadian Journal of Emergency Medicine, and today we'll be interviewing Dr. Machiavelli of ... (OFF CAMERA SCREAMS) ... My goodness ... what was that blood-curdling scream?

Dr. Machiavelli: The patient in room 5 is having a foreign body removal. We save time by forgoing analgesia. It's our new Ottawa More-than-Aggressive Protocol.

CJEM: Wow, that is aggressive. What about patient satisfaction?!

DR. M: Satisfaction? I don't remember that being a line item on my pay cheque. There's more security in being feared than loved. Besides, I give midazolam after the procedure. Retrograde amnesia is a beautiful thing; and it's quicker than putting them down, which is what I used to do.

CJEM: Putting them down? But Dr. Machiavelli, even with your reputation for ruthless efficiency, I never thought you would consider euthanasia a treatment alternative.

DR. M: No, no, not euthanasia. I needed a little malleability. I put them "down" with haloperidol. I'm thinking about giving it at triage.

CJEM: Actually, I noticed you don't have much of a triage process.

DR. M: No, triage just tells you how long you will wait. I've brought in the most underpaid midlevel providers I could find to take care of the CTAS- 4 and -5 patients so there will be no wait.
CJEM: Oh, are you using nurse practitioners or physician assistants? They're quite controversial.

DR. M: Neither. I hired off-duty psychiatrists. They needed the extra money and they appreciate a little medicine now and then.

CJEM: Psychiatrists? They know virtually nothing about emergency medicine!

DR. M: No, but you should see them order selective serotonin reuptake inhibitors!! There's a drug class that's used for chronic pain, headaches, insomnia everything under the sun; and the psychiatrists are great for patient satisfaction.

CJEM: So you do care about patient satisfaction?

DR. M: Not directly. Compassion only slows me down. I care if it makes my job easier or increases my power; and power will help in our preparation for war.

CJEM: War?!

DR. M: That's how I see it. I see a great turf war between us and the Specialists. I fear they will fight us to the death. For instance, we're going to introduce some new technologies in the ED that I'm hoping to bill for.

CJEM: Are you referring to ultrasound?

DR. M: No. I've been looking at laparoscopy and stenting. I'm also considering tattoo removal, Botox and LASIK. I've watched videos on YouTube and they all look easy. My feelings on procedures are, if it's quick, efficient and leads to discharge, we should do it!

CJEM: But aren't you too busy seeing the emergency patients to do more procedures?

DR. M: No. I've taken care of that by hiring more underpaid midlevel providers.

CJEM: More psychiatrists?

DR. M: No. I've hired pediatricians, generalists and

Continued on page 507

From the Department of Emergency Medicine, University of Michigan, Ann Arbor, Mich.

Submitted Jun. 29, 2009; Revised Jul. 18, 2009; Accepted Jul. 20, 2009

This article has not been peer reviewed.

CJEM 2009;11(5):508; 507 


\section{Continued from page 508}

internists. They needed the money too and I still take my percentage cut.

CJEM: Well it sounds efficient, but you can't discharge everyone. How have you solved the overcrowding issue? No one else has beds.

DR. M: I'm not afraid to prescribe long-acting opiates. A third of our patients have chronic pain. By widespread prescribing of opiates, I've solved the ED chronic pain problem. In fact, if it was up to me, we would have overthe-counter opiates. Let's sell and tax all narcotics just like we do alcohol. Then we can stop wasting money on the war on street drugs and fighting in Afghanistan. Spend the money on addiction treatment and research — and hand out free naloxone autoinjectors.

CJEM: You're right. We could spend more research money for disasters and pandemic disease.

DR. M: No, I wouldn't spend money on that. Pandemics and disasters are nature's plan to decrease ED overcrowding.
CJEM: Surely you've had a problem finding enough nursing staff?

DR. M: No. We pay our nursing staff on a fee-for-service basis. Suddenly, they see more than the usual 4:1 ratio.

CJEM: Fee-for-service nursing? The staff must appreciate your generosity.

DR. M: No, I'm not that generous. If I were, they would only expect more and resent me when I withheld my benevolence.

CJEM: That's an interesting philosophy.

DR. M: It's actually not my philosophy. I learned it from the provincial government during our fee negotiations.

CJEM: So your departmental statistics must look great.

DR. M: Yes, all my means are improving: mean length of stay, mean time to physician, mean time to discharge. And you know what they say: "The ends justify the means."

Competing interests: None declared.

Keywords: Machiavelli, emergency, crowding

Correspondence to: Dr. Jeffrey Freeman; jfree4@yahoo.com

\section{Change of address}

We require 6 to 8 weeks' notice to ensure uninterrupted service. Please send your current mailing label, new address and the effective date of change to:

\section{Canadian Association of Emergency Physicians}

104-1785 Alta Vista Dr. Ottawa ON K1G 3 Y6

$613523-3343$

fax $613523-0190$

admin@caep.ca

\section{Changement d'adresse}

II nous faut de 6 à 8 semaines d'avis afin de vous assurer une livraison ininterrompue. Veuillez faire parvenir votre étiquette d'adresse actuelle, votre nouvelle adresse et la date de la prise d'effet du changement, à l'attention du

\section{Association canadienne des médecins d'urgence}

104-1785, prom. Alta Vista

Ottawa ON K1G 3 Y6

613 523-3343

fax 613 523-0190

admin@caep.ca 